\title{
Ispitivanje fizikalno-kemijskih pokazatelja kvalitete voda
}

DOI: $10.15255 / \mathrm{KUI} .2015 .045$

KUI-35/2016

Stručni rad

Prispjelo 20. listopada 2015.

Prihvaćeno 24. studenoga 2015.

\author{
A. Ptiček Siročić, ${ }^{a^{*}}$ N. Fujs i i N. Glumac ${ }^{c}$ \\ a Geotehnički fakultet, Sveučilište u Zagrebu, Hallerova aleja 7, 42000 Varaždin, Hrvatska \\ b Tehnix d.o.o., Braće Radića bb, 40320 Donji Kraljevec, Hrvatska \\ c Međimurske vode d.o.o., Matice hrvatske 10, 40000 Čakovec, Hrvatska
}

\begin{abstract}
\| Sažetak
U ovom su radu analizirani fizikalno-kemijski pokazatelji kakvoće otpadnih voda (kemijska potrošnja kisika (KPK), biokemijska potrošnja kisika $\left(\mathrm{BPK}_{5}\right)$, koncentracija suspendiranih tvari) tijekom ljetnih mjeseci (lipanj, srpanj i kolovoz) 2013. i 2014. godine na centralnom uređaju za pročišćavanje otpadnih voda Cakovec, koji je predviđen za drugi stupanj pročišćavanja. Ljetni mjeseci 2014. godine ne pokazuju značajnija odstupanja vrijednosti pojedinih pokazatelja, ali u odnosu na iste mjesece u 2013. godini srednje mjesečne vrijednosti znatno su niže i nalaze se unutar dopuštenih maksimalnih koncentracija. Rezultati za lipanj, srpanj i kolovoz 2013. i 2014. godine ukazuju na učinkovito pročišćavanje otpadnih voda na pročistaču.
\end{abstract}

\| Ključne riječi

Fizikalno-kemijski pokazatelji, otpadne vode, pročistač otpadnih voda, kemijska potrošnja kisika, biokemijska potrošnja kisika, suspendirane tvari

\section{Uvod}

Razvoj industrije, eksponencijalni rast stanovništva kao i povećanje proizvodnje znatno utječu na porast količine otpadnih tvari koje se izravno ili neizravno ispuštaju u prirodne vodne sustave. Ovisno o veličini prihvatne sposobnosti pojedinih prijamnika potrebno je određeno vrijeme kako bi se opazili eventualni poremećaji prirodne biološke ravnoteže dijelova vodnih sustava. Teško poremećeni dijelovi prirodnog okoliša, osobito voda, ubrzo postaju neupotrebljivi za mnoge namjene. Da bi se zaštitila kvaliteta prirodnih vodnih sustava, komunalne otpadne vode prije ispuštanja u okoliš moraju udovoljiti određenim uvjetima kvalitete. Zahvati različitih namjena voda ujedno su mjesta čovjekove intervencije u hidrološki ciklus jer voda više ne slijedi zakone hidrološkog ciklusa, nego se podvrgava zakonima ljudskih htijenja. Kako bi se otpadne vode mogle na zadovoljavajući način pročistiti i ispustiti u prijamnike, potrebno je analizirati učinkovitost pročišćavanja i djelovati na odgovarajući način. Analizirati učinkovitost pročišćavanja znači ispitati fizikalne, kemijske i biološke pokazatelje kvalitete vode na ulazu i izlazu iz pročistača. U Republici Hrvatskoj na sustav javne vodoopskrbe priključeno je oko 76 \% stanovništva, na sustave kanalizacije manje od $50 \%$, a pročišćava se samo $35 \%$ otpadnih voda, od čega na zadovoljavajući način tek nešto više od $10 \%$. U ovom radu analizirani su fizikalno-kemijski pokazatelji kvalitete otpadne vode (kemijska potrošnja kisika, KPK; biokemijska potrošnja kisika, $\mathrm{BPK}_{5}$ i koncentracija suspendiranih tvari) tijekom ljetnih mjeseci (lipanj, srpanj, kolovoz) 2013. i 2014. godine na centralnom uređaju za pročišćavanje otpadnih voda Čakovec.

\footnotetext{
*Autor za dopisivanje: doc. dr. sc. Anita Ptiček Siročić e-pošta: anitaps@gfv.hr
}

\section{Eksperimentalni dio}

Za provedbu analize fizikalno-kemijskih pokazatelja kvalitete vode uzeti su uzorci otpadne vode na ulazu i izlazu iz centralnog uređaja za pročišćavanje otpadne vode u Čakovcu. Automatski uzorkivač sadrži 12 posuda za čuvanje 24-satnog kompozitnog uzorka otpadne vode, a automatika i doziranje uzoraka otpadne vode proporcionalna je protoku, s obzirom na to da je crpka povezana s mjeračem protoka. Kompozitni uzorci uzimani su svakodnevno radi utvrđivanja ulaznih pokazatelja i optimizacije tehnološkog procesa čišćenja otpadne vode.

\subsection{Određivanje kemijske potrošnje kisika ${ }^{1}$}

Kemijska potrošnja kisika određena je na spektrofotometru HACH DR $4000 U$ u koncentracijskom području 0,0 - $1000 \mathrm{mgl}^{-1}$ kisika. Pripremljeni reagens (kalijev dikromat, živin(II) sulfat i srebrov sulfat) odmjeren je u čiste začepljene kivete kao i uzorak otpadne vode. Kivete se stave u KPK-reaktor i kuhaju 2 sata na temperaturi $150^{\circ} \mathrm{C}$. Slijepa proba priprema se na isti način $\mathrm{s}$ destiliranom vodom. Nakon kuhanja uzorak se ohladi i mjeri se apsorbancija pri valnoj duljini od $600 \mathrm{~nm}$ u odnosu na slijepu probu.

\subsection{Određivanje biokemijske potrošnje kisika²}

BPK $_{5}$ (biološka potrošnja kisika nakon pet dana) određuje se s pomoću uređaja OxiTop. Temperatura uzorka podesi se na $20^{\circ} \mathrm{C}$, a pH na $6-8$. U staklenu tikvicu odmjeri se određeni volumen homogeniziranog uzorka (ovisno o očekivanoj koncentraciji utrošenog kisika u nakon 5 dana) te se prebaci u bočicu od tamnog stakla. Doda se određeni 
broj kapi inhibitora nitrifikacije (1 kap na $50 \mathrm{ml}$ uzorka), stavi se magnetić u bočicu te gumeni nastavak na grlo bočice u koji se stave dvije granule $\mathrm{NaOH}$. Uzorak se stavi u prethodno podešen termostat na $20 \pm 1{ }^{\circ} \mathrm{C}$ i nakon 5 dana očita se rezultat.

\subsection{Određivanje suspendirane tvari ${ }^{3}$}

Osušen i u eksikatoru ohlađen filtar-papir potrebno je vagnuti i zabilježiti odvagu. Filtar-papir se stavi na vakuumsku sisaljku te se ispere malom količinom destilirane vode. Određeni volumen izmiješanog uzorka (ovisno o količini suspendirane tvari koja se očekuje) profiltrira se preko filtar-papira, ispere malom količinom destilirane vode te stavi u sušionik na $105^{\circ} \mathrm{C}$ oko 60 min. Osušeni filtar-papir stavi se u eksikator na hlađenje najmanje 30 - 60 minuta, zatim se važe i zabilježi odvaga.

\section{Rezultati i rasprava}

U gradu Čakovcu izgrađen je miješani kanalizacijski sustav što znači da na uređaj za pročišćavanje otpadnih voda dolaze kućanske otpadne vode kao i oborinske otpadne vode. Na uređaj za pročíšćavanje također dolaze i industrijske otpadne vode s obzirom na to da nema posebnog kanalizacijskog sustava, a ni uređaja za pročišćavanje industrijskih otpadnih voda. Uređaj za pročišćavanje otpadnih voda Čakovec predviđen je za drugi stupanj pročišćava-

Tablica 1 - Utjecaj industrije na pojedine pokazatelje kakvoće vode $^{5-8}$

Table 1 - The impact of industry on indicators of water quality ${ }^{5-8}$

\begin{tabular}{|c|c|}
\hline $\begin{array}{l}\text { Industrija } \\
\text { Industry }\end{array}$ & $\begin{array}{l}\text { Pokazatelji } \\
\text { Indicators }\end{array}$ \\
\hline $\begin{array}{l}\text { tekstilna industrija } \\
\text { textile industry }\end{array}$ & $\begin{array}{l}\text { KPK, krutine, kiseline, lužine, } \\
\text { površinski aktivne tvari } \\
\text { COD, solids, acids, bases, surfactants }\end{array}$ \\
\hline $\begin{array}{l}\text { površinska obrada } \\
\text { metala } \\
\text { surface treatment of } \\
\text { metals }\end{array}$ & $\begin{array}{l}\text { kiseline, lužine, metali, cijanidi, } \\
\text { površinski aktivne tvari, masti } \\
\text { acids, bases, metals, cyanides, } \\
\text { surfactants, fats }\end{array}$ \\
\hline $\begin{array}{l}\text { celuloza i papir } \\
\text { cellulose and paper }\end{array}$ & $\begin{array}{l}\text { KPK, krutine, lužine } \\
\text { COD, solids, bases }\end{array}$ \\
\hline $\begin{array}{l}\text { prehrambena industrija } \\
\text { food industry }\end{array}$ & $\begin{array}{l}\text { BPK, krutine, masnoće } \\
\text { BOD, solids, fats }\end{array}$ \\
\hline $\begin{array}{l}\text { koksare } \\
\text { coke oven }\end{array}$ & $\begin{array}{l}\text { KPK, cijanidi, spojevi sumpora } \\
\text { COD, cyanides, sulphur compounds }\end{array}$ \\
\hline $\begin{array}{l}\text { kožarska industrija } \\
\text { leather industry }\end{array}$ & $\begin{array}{l}\text { BPK, krutine, sulfidi, metali, lužine } \\
\text { BOD, solids, sulphides, metals, bases }\end{array}$ \\
\hline $\begin{array}{l}\text { umjetna gnojiva } \\
\text { fertilizers }\end{array}$ & $\begin{array}{l}\text { KPK } \\
\text { COD }\end{array}$ \\
\hline $\begin{array}{l}\text { petrokemijska industrija } \\
\text { petrochemical industry }\end{array}$ & $\begin{array}{l}\text { kiseline, lužine, sumporni spojevi } \\
\text { acids, bases, sulphur compounds }\end{array}$ \\
\hline $\begin{array}{l}\text { farmaceutska industrija } \\
\text { pharmaceutical industry }\end{array}$ & $\begin{array}{l}\text { KPK, kiseline, lužine } \\
\text { COD, acids, bases }\end{array}$ \\
\hline
\end{tabular}

nja otpadnih voda. Pravilnikom o graničnim vrijednostima emisija otpadnih voda (NN 80/2013), ${ }^{4}$ za drugi stupanj pročiśćavanja otpadnih voda propisano je određivanje $\mathrm{KPK}, \mathrm{BPK}_{5}$ i suspendiranih tvari, stoga su u radu analizirani navedeni pokazatelji. Koncentracije ulaznih pokazatelja $\mathrm{KPK}, \mathrm{BPK}_{5}$ i suspendiranih tvari na uređaju za pročišćavanje nisu konstantne vrijednosti jer uvelike ovise o antropogenim aktivnostima i meteorološkim prilikama. Trenutačno aktivne industrije u gradu Čakovcu i prigradskim mjestima su tekstilna, metalska, grafička, mesna, mljekarska i mlinarska industrija. Ispuštanjem otpadnih voda industrije znatno doprinose povišenim vrijednostima koncentracija pokazatelja $\mathrm{KPK}, \mathrm{BPK}_{5}$, suspendiranih tvari kao i ostalih pokazatelja kakvoće vode, tablica 1.

U ovom radu prikazane su vrijednosti pokazatelja KPK, $\mathrm{BPK}_{5}$ i suspendiranih tvari za svaki dan u ljetnim mjesecima (lipanj, srpanj, kolovoz) 2013. i 2014. godine. Na slici 1 prikazane su ulazne i izlazne vrijednosti KPK, $\mathrm{BPK}_{5} \mathrm{i}$ suspendiranih tvari za lipanj 2013. godine u usporedbi s vrijednostima prema tada važećim pravilnicima NN $87 / 10^{9}$ i NN 80/13. ${ }^{4}$
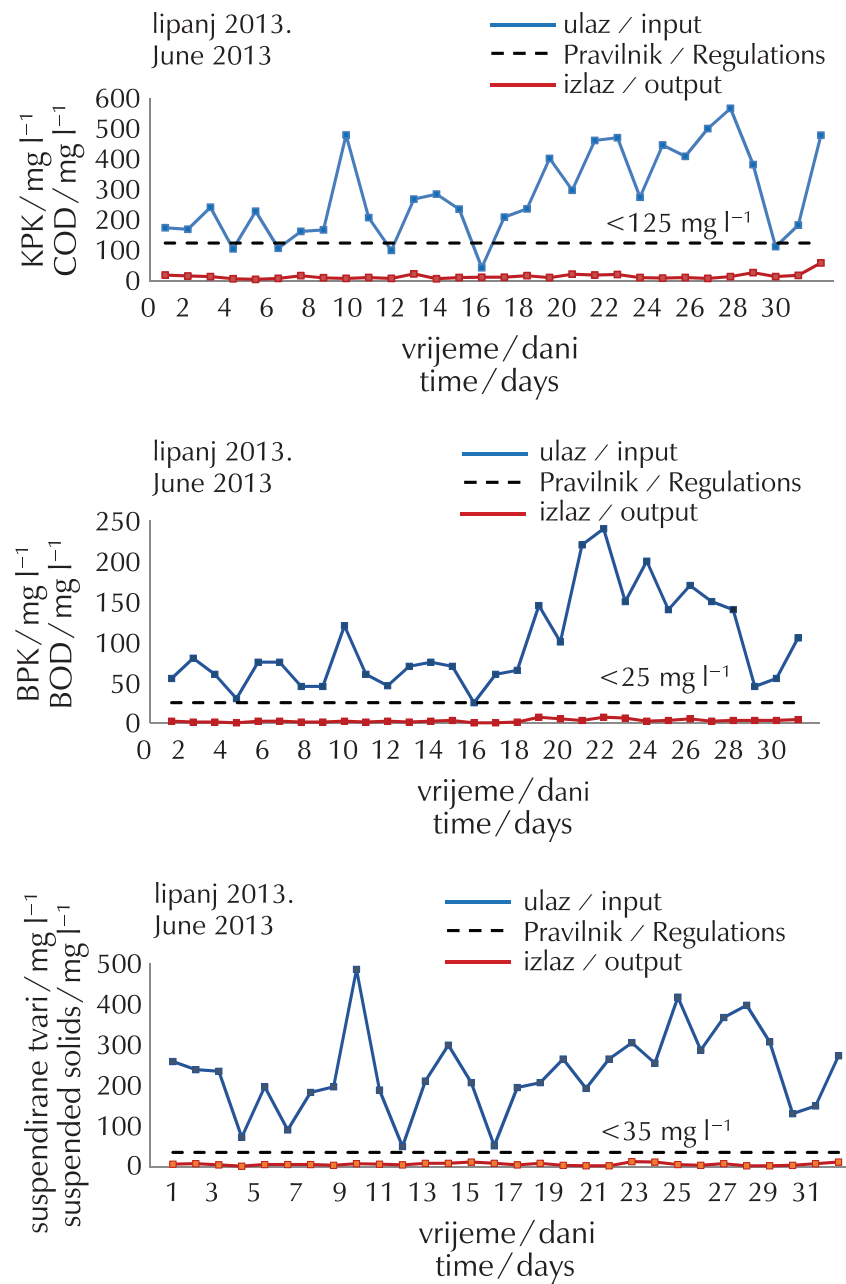

Slika 1 - KPK, BPK ${ }_{5}$ i koncentracija suspendirane tvari u lipnju 2013. godine

Fig. 1 - $\mathrm{COD}, \mathrm{BOD}_{5}$ and concentration of suspended solids in June 2013 
Ulazne vrijednosti pokazatelja pokazuju velike naizmjenične oscilacije što je posljedica zadržavanja ulazne otpadne vode u retencijskom bazenu. Naime, krute se čestice istalože na dno što uzrokuje niže koncentracije organskog i anorganskog onečišćenja na površini, a više koncentracije onečišćenja prisutne su na dnu bazena što ima kao posljedicu niže vrijednosti $\mathrm{KPK}, \mathrm{BPK}_{5}$ i suspendiranih tvari. Iz slike je vidljivo da se ulazne vrijednosti KPK za lipanj 2013. godine kreću u rasponu $44-566 \mathrm{mgl}^{-1}$; ulazne vrijednosti $\mathrm{BPK}_{5} \mathrm{kreću}$ se u rasponu 25 - $240 \mathrm{mg} \mathrm{l}^{-1}$, dok su za suspendirane tvari ulazne vrijednosti u rasponu $49-484 \mathrm{mgl}^{-1}$. Vrijednosti pokazatelja $\mathrm{KPK}, \mathrm{BPK}_{5}$ i suspendiranih tvari nalaze se unutar intervala karakterističnih vrijednosti za mješoviti kanalizacijski sustav ${ }^{5}$ prema tablici 2.

Tablica 2 - Pokazatelji otpadne vode mješovite kanalizacije Table 2 - Indicators of mixed sewage wastewater

\begin{tabular}{c|c}
\hline $\begin{array}{c}\text { Pokazatelj } \\
\text { Indicator }\end{array}$ & $\begin{array}{c}\text { Vrijednosti } / \mathrm{mgl}^{-1} \\
\text { Values } / \mathrm{mgl}^{-1}\end{array}$ \\
\hline KPK & $80-1760$ \\
COD & $10-470$ \\
BPK $_{5}$ & \\
BOD $_{5}$ & $35-2000$ \\
suspendirane tvari \\
suspended solids
\end{tabular}

Kao što je vidljivo iz slike 1, ulazne su koncentracije suspendiranih tvari povišene što se u velikoj mjeri može pripisati utjecaju oborina. Oborinske vode, koje ispiru atmosferu kao i površine gradova i naselja, međusobno se bitno razlikuju, ali im je zajednička značajka da su pri početnom ispiranju površina koncentracije suspendiranih tvari ponekad više od koncentracija u kućanskim otpadnim vodama. ${ }^{11,12}$ Nakon duljeg ispiranja površina koncentracija suspendiranih tvari u oborinskim vodama se smanjuje. Međutim, vrijednosti za sve pokazatelje nisu usporedive zbog zadržavanja vode u retencijskom bazenu i načinu rada crpki.

Nakon postupka pročišćavanja vidljivo je da su vrijednosti svih ispitivanih pokazatelja u lipnju 2013. godine unutar dopuštenih graničnih vrijednosti prema tada važećim pravilnicima. ${ }^{4,9}$ Također je vidljivo da su izlazne vrijednosti svih pokazatelja gotovo konstantne te se može zaključiti da je učinkovitost uređaja zadovoljavajuća unatoč ulaznim oscilacijama.

Na slici 2 prikazane su ulazne i izlazne vrijednosti pokazatelja KPK, BPK 5 i suspendiranih tvari za srpanj 2013. godine. Usporedbom dobivenih vrijednosti $\mathrm{KPK} \mathrm{i} \mathrm{BPK}_{5}$ za mjesec lipanj i srpanj (slika 1 i slika 2) vidljivo je znatno povećanje ulaznih koncentracija u mjesecu srpnju. Razlog povišenih ulaznih parametra pripisuje se povećanoj potrošnji vode u kućanstvima jer mjesec srpanj karakterizira početak godišnjih odmora. Prema navedenim podatcima izlazne vrijednosti svih pokazatelja određenih u srpnju nalaze se u rasponu dopuštenih vrijednosti prema tablici 2 .
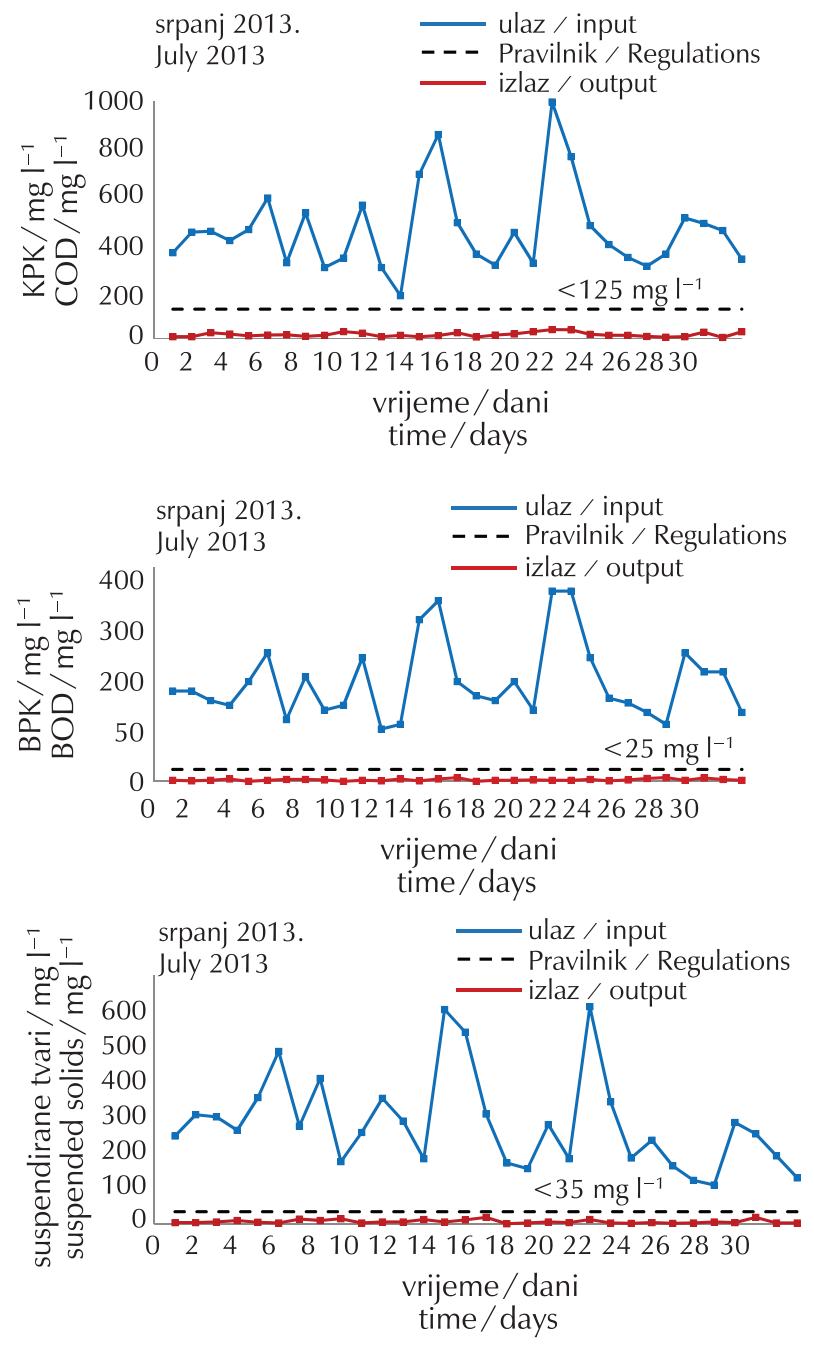

Slika 2 - KPK, $\mathrm{BPK}_{5}$ i koncentracija suspendirane tvari u srpnju 2013. godine

Fig. 2 - $\mathrm{COD}, \mathrm{BOD}_{5}$ and concentration of suspended solids in July 2013

Na slici 3 prikazane su ulazne i izlazne vrijednosti pokazatelja KPK, $\mathrm{BPK}_{5}$ i suspendiranih tvari u kolovozu 2013. godine. Ulazne vrijednosti pokazatelja KPK kreću se u rasponu 109 - $1236 \mathrm{mgl}^{-1}$ sa srednjom mjesečnom vrijednošću 401,5 $\mathrm{mgl}^{-1}$. Ulazne vrijednosti $\mathrm{BPK}_{5}$ kreću se u rasponu $36-520 \mathrm{mgl}^{-1}$ sa srednjom mjesečnom vrijednošću $176,1 \mathrm{mgl}^{-1}$. Ulazne vrijednosti suspendiranih tvari nalaze se u rasponu $30-864 \mathrm{mgl}^{-1}$, dok srednja mjesečna vrijednost iznosi $241,9 \mathrm{mgl}^{-1}$. lako su ulazne vrijednosti svih pokazatelja znatnije povećane u odnosu na prethodna dva mjeseca, srednje mjesečne vrijednosti za sve ispitivane pokazatelje pokazuju blagi pad u odnosu na srpanj 2013. godine. ${ }^{13-15}$ Ako se dobivene vrijednosti usporede $s$ karakterističnim vrijednostima pokazatelja mješovitog kanalizacijskog sustava (tablica 2), može se zaključiti da, iako znatno povišene, još su uvijek u dopuštenom intervalu. 

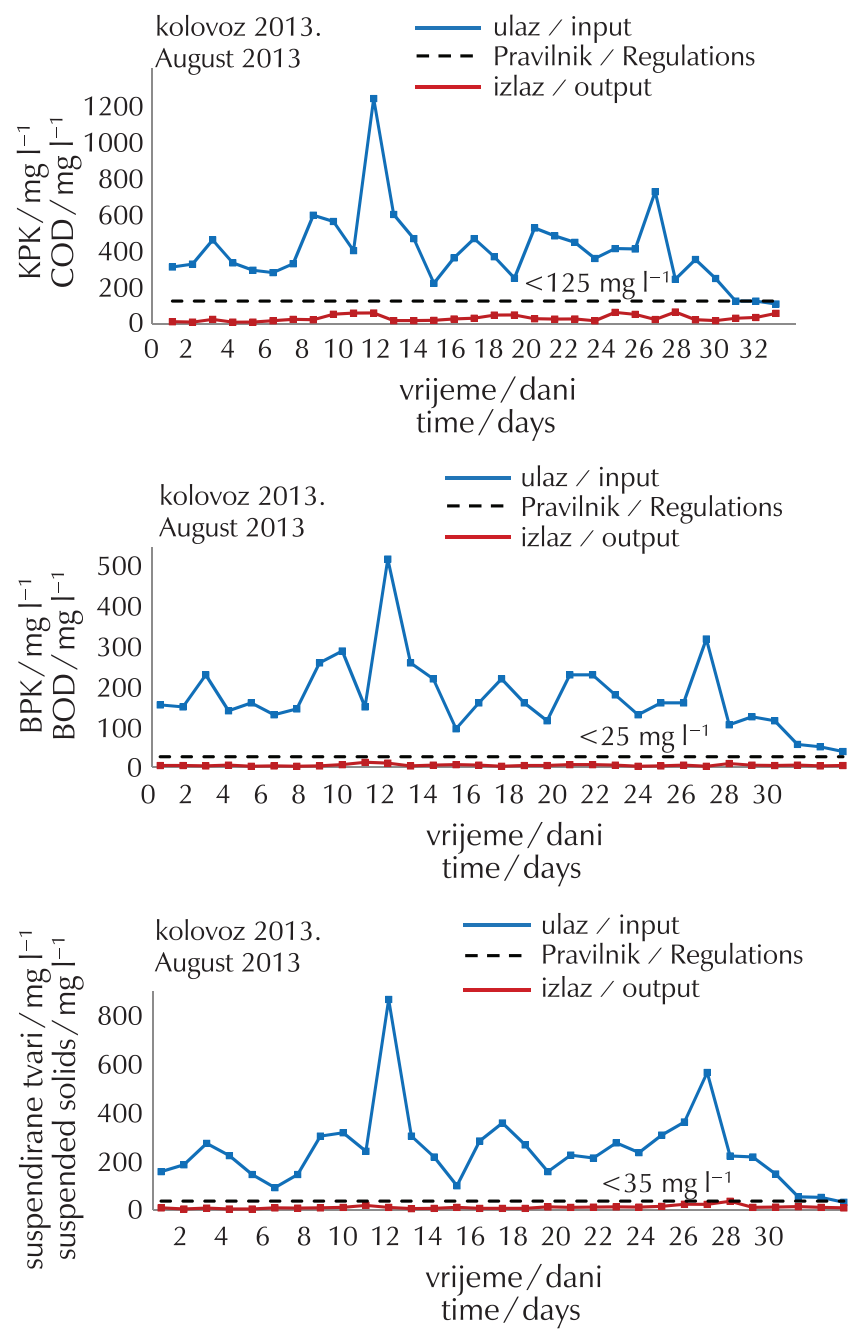

Slika 3 - KPK, BPK i koncentracija suspendirane tvari u kolovozu 2013. godine

Fig. 3 - $\mathrm{COD}, \mathrm{BOD}_{5}$ and concentration of suspended solids in August 2013

Međutim, vrlo izražen porast vrijednosti svih mjerenih pokazatelja 11. dana u kolovozu 2013. (slika 3) u odnosu na ostale dane u mjesecu,može se pripisati ispuštanju otpadnih voda iz septičkih jama. Poznato je iz literature ${ }^{5}$ da septičke jame sadrže vrlo visoke koncentracije ispitivanih pokazatelja, tablica 3.

Tablica 3 - Otpadne tvari u vodama iz septičkih jama

Table 3 - Waste substances in the waters from septic tanks

\begin{tabular}{c|c}
\hline $\begin{array}{c}\text { Pokazatelj } \\
\text { Indicator }\end{array}$ & $\begin{array}{c}\text { Vrijednosti } / \mathrm{mgl}^{-1} \\
\text { Values } / \mathrm{mgl}^{-1}\end{array}$ \\
\hline $\begin{array}{c}\text { suspendirane tvar } \\
\text { suspended solids } \\
\mathrm{BPK}_{5}\end{array}$ & $5000-17000$ \\
$\mathrm{BOD}_{5}$ & $4000-10000$ \\
KPK & $6000-16000$ \\
COD &
\end{tabular}

Prema tome može se zaključiti da završavanjem godišnjih odmora pojedini ulazni pokazatelji karakteristični za
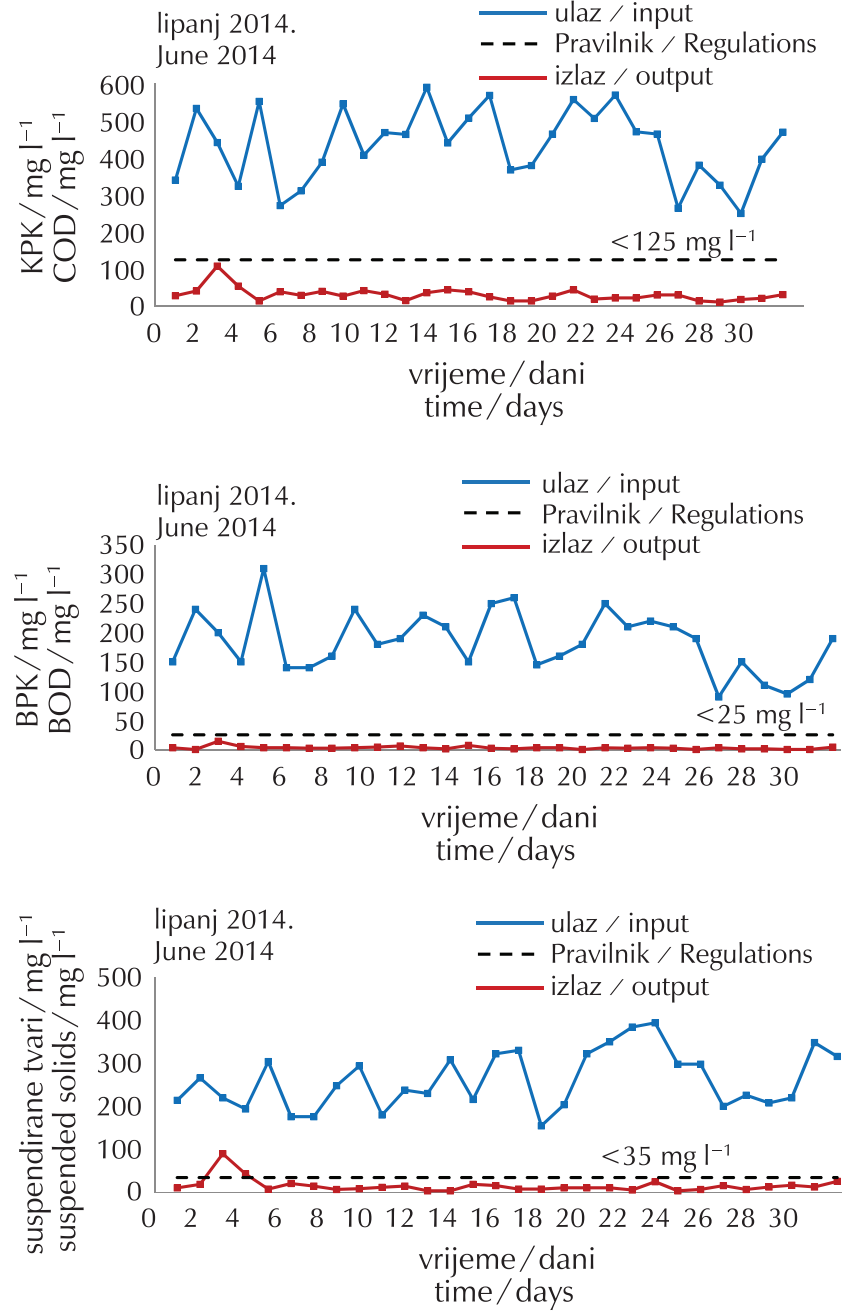

Slika 4 - Vrijednosti koncentracija KPK, $\mathrm{BPK}_{5}$ i suspendiranih tvari u lipnju 2014. godine

Fig. 4 - Values of COD, $\mathrm{BOD}_{5}$ and suspended solids in June 2014

otpadne vode ukazuju na početak rada u industrijama te manju aktivnost ljudi u kućanstvima.

Ljetne mjesece 2014. godine obilježile su neuobičajeno velike količine padalina te je zbog toga bilo i očekivano drugačije ponašanje ispitivanih pokazatelja. U lipnju 2014. godine (slika 4) ulazne vrijednosti KPK kreću se u rasponu 250 - $590 \mathrm{mgl}^{-1}$, a srednja mjesečna vrijednost iznosi $433,6 \mathrm{mgl}^{-1}$. Vrijednosti pokazatelja $\mathrm{BPK}_{5}$ na ulazu u pročistač kreću se u rasponu $90-310 \mathrm{mgl}^{-1}$ sa srednjom mjesečnom vrijednošću $184 \mathrm{mgl}^{-1}$, dok se ulazne vrijednosti suspendiranih tvari kreću u rasponu 155 - $394 \mathrm{mgl}^{-1}$, a srednja mjesečna vrijednost iznosi $261,3 \mathrm{mgl}^{-1}$. Vrijednosti svih ispitivanih pokazatelja u lipnju nalaze se unutar raspona karakterističnih za mješovitu kanalizaciju (tablica 2). Zanimljive su izlazne vrijednosti svih promatranih pokazatelja trećeg dana u lipnju 2014. godine. Tog su dana izlazne vrijednosti svih pokazatelja bile znatno povećane u odnosu na ostale dane u mjesecu, a osobito je povećana koncentracija suspendiranih tvari, koja je znatno iznad dopuštene vrijednosti propisane Pravilnikom (NN 80/134 i 43/14 ${ }^{10}$ ). Izlazna vrijednost koncentracije suspendiranih tvari ne može se pripisati industrijskim aktivnostima. Uzrok naglom povećanju 
vrijednosti je priključenje kanalizacijske grane na glavnu granu odvodnje pa je bilo potrebno isprazniti kanalizaciju. Na uređaju za pročišćavanje otpadnih voda u Čakovcu uobičajeno rade dvije crpke na ulazu, a tog su dana radile sve četiri, čime se znatno povećalo opterećenje pročistača i uzrokovalo nagli porast vrijednosti. Isto tako mogu se primijetiti povišene izlazne vrijednosti svih pokazatelja tijekom pojedinih dana istoga mjeseca, što se također može pripisati postavljanju novih kanalizacijskih grana što je smanjilo efikasnost rada uređaja s obzirom na to da je bilo potrebno određeno vrijeme za stvaranje optimalne količine aktivnog mulja u bioaeracijskim bazenima. lako su izlazne vrijednosti pokazatelja povišene u odnosu na prethodnu godinu za isti mjesec, sve se vrijednosti nalaze ispod maksimalno dopuštenih koncentracija prema Pravilniku (NN 80/134 i 43/14 ${ }^{10}$ ) osim za suspendirane tvari na početku lipnja 2014. godine.

Na slici 5 prikazane su vrijednosti koncentracija ispitivanih pokazatelja za srpanj 2014. godine. U srpnju 2014. godine opterećenje na ulazu u pročistač bilo je povišeno u odnosu na promatrane mjesece u 2013. godini. Ulazne vrijednosti pokazatelja KPK nalaze se $\mathrm{u}$ rasponu $86-572 \mathrm{mgl}^{-1}$ sa srednjom mjesečnom vrijednošću $300,1 \mathrm{mgl}^{-1}$. Ulazne vri-
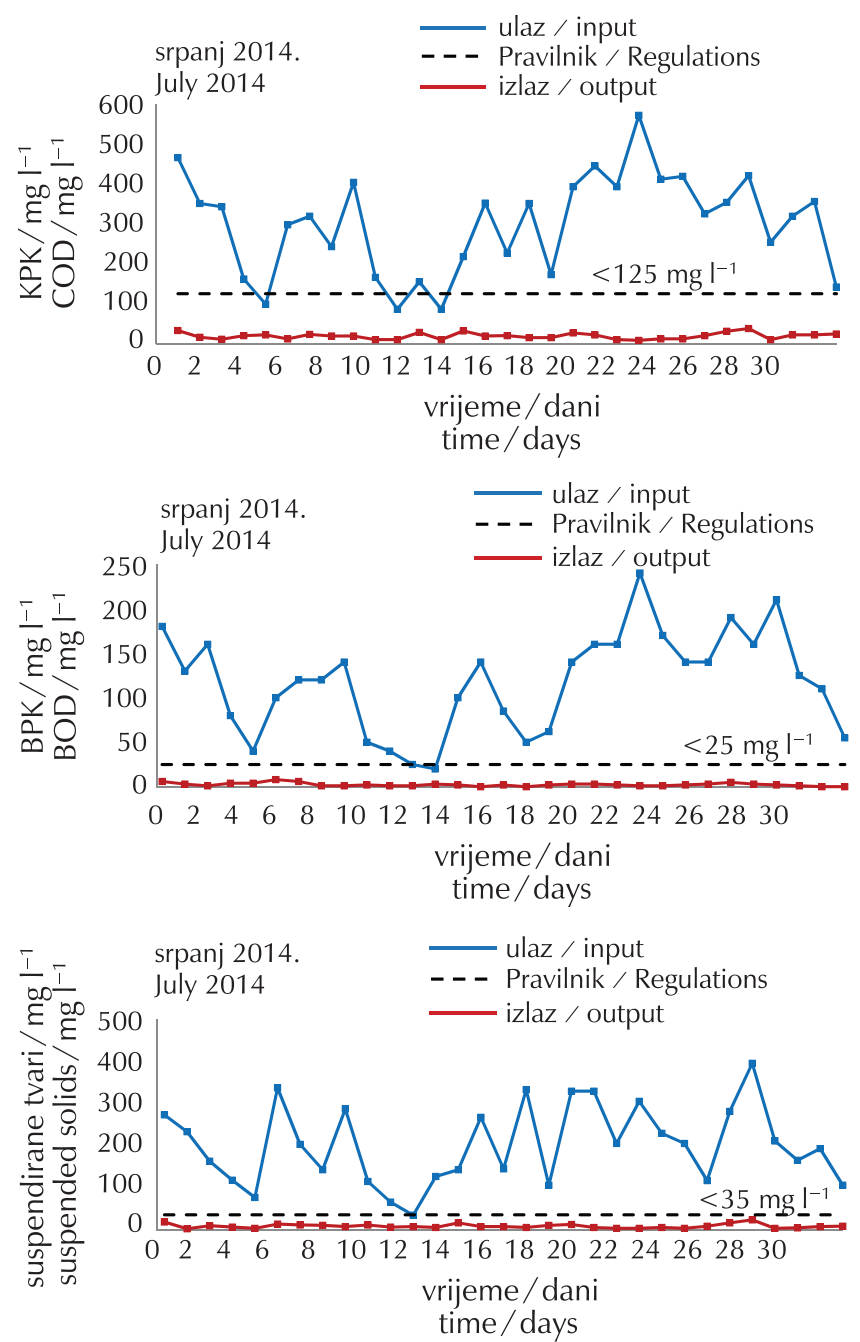

Slika 5 - Vrijednosti koncentracija $\mathrm{KPK}, \mathrm{BPK}_{5}$ i suspendiranih tvari u srpnju 2014. godine

Fig. 5 - Values of COD, BOD 5 and suspended solids in July 2014 jednosti $\mathrm{BPK}_{5}$ nalaze se u rasponu $20-240 \mathrm{mgl}^{-1}$ dok je srednja vrijednost $117,5 \mathrm{mgl}^{-1}$. Koncentracija suspendiranih tvari kreće se u rasponu $34-394 \mathrm{mgl}^{-1}$ sa srednjom mjesečnom vrijednošću 200,3 $\mathrm{mgl}^{-1}$. Uspoređujući rezultate svih pokazatelja određenih u srpnju 2014. godine s rezultatima dobivenim u lipnju uočena su sniženja prosječnih vrijednosti, kako na ulazu tako i na izlazu iz pročistača. Smanjene srednje mjesečne vrijednosti ulaznih pokazatelja u srpnju 2014. godine u odnosu na lipanj iste godine mogu se pripisati meteorološkim prilikama koje su doprinijele razrjeđenju koncentracija. Izlazne vrijednosti svih pokazatelja nalaze se unutar maksimalno dopuštenih koncentracijama prema važećem Pravilniku. Nadalje, izlazne vrijednosti ispitivanih pokazatelja su relativno konstantne, te se može zaključiti da je u bioaeracijskim bazenima došlo do optimizacije aktivnog mulja, poremećenog u prethodnom mjesecu kada se priključivala kanalizacijska grana.

Kolovoz 2014. godine bio je izrazito kišovit te su srednje ulazne i izlazne vrijednosti pokazatelja $\mathrm{KPK}, \mathrm{BPK}_{5}$ i suspendiranih tvari još niže nego u srpnju te godine. Povećane količine padalina posebno su bile izražene u drugoj polovici mjeseca. Na slici 6 prikazane su ulazne vrijednosti
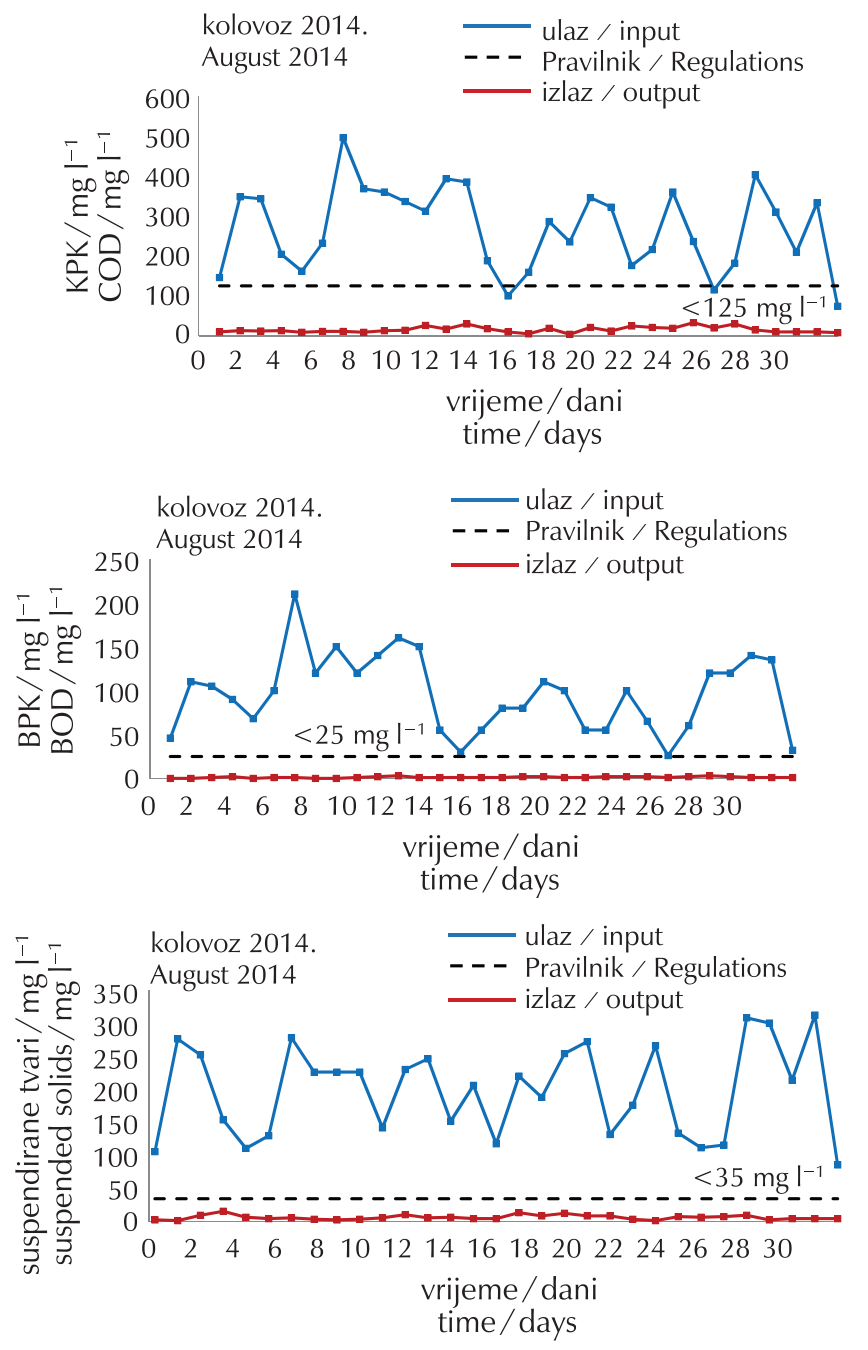

Slika 6 - Vrijednosti koncentracija KPK, $\mathrm{BPK}_{5}$ i suspendiranih tvari u kolovozu 2014. godine

Fig. 6 - Values of COD, BOD ${ }_{5}$ and suspended solids in August 2014 
koncentracije KPK u rasponu $74-496 \mathrm{mgl}^{-1}$ sa srednjom mjesečnom vrijednošću 268,9 $\mathrm{mgl}^{-1}$. Raspon ulaznih vrijednosti pokazatelja $\mathrm{BPK}_{5}$ kreće se između 26 i $210 \mathrm{mgl}^{-1}$ sa srednjom mjesečnom vrijednošću 96,4 $\mathrm{mgl}^{-1}$, dok je raspon ulaznih vrijednosti suspendiranih tvari između 86 i $312 \mathrm{mgl}^{-1}$, a srednja mjesečna vrijednost iznosi $199 \mathrm{mgl}^{-1}$. Kako je već ranije spomenuto, visoke koncentracije suspendiranih tvari uzrokovane padalinama najčešće se javljaju samo u početnom dijelu trajanja padalina, pri čemu dolazi do najvećeg ispiranja zemljišta, gradskih površina i atmosfere. Izlazne vrijednosti svih pokazatelja nalaze se unutar maksimalno dopuštenih vrijednosti prema važećem Pravilniku, ${ }^{10}$ a pokazuju i kontinuitet što dokazuje izvrsnu efikasnost uređaja za pročišćavanje otpadnih voda.

\section{Zaključak}

U sklopu centralnog uređaja za pročišćavanje otpadnih voda Cakovec analizirani su rezultati fizikalno-kemijskih pokazatelja (KPK, $\mathrm{BPK}_{5}$ i suspendiranih tvari) za lipanj, srpanj i kolovoz 2013. i 2014. godine. Usporede li se vrijednosti ispitivanih pokazatelja za ljetne mjesece u 2013. godini, vidljiv je porast ulaznih vrijednosti tijekom mjeseca srpnja i kolovoza u odnosu na lipanj 2013. godine dok su izlazne vrijednosti svih pokazatelja unutar dopuštenih maksimuma. Ljetni mjeseci u 2014. godini također pokazuju isti trend. Općenito, tijekom promatranog razdoblja, vrijednosti pokazatelja na izlazu iz pročistača gotovo su u svim slučajevima ispod propisanih maksimalnih dopuštenih koncentracija, te se na temelju toga može zaključiti da je uređaj vrlo učinkovit, te se tako pročišćena voda može ispustiti u prirodne vodotokove.

\section{Popis kratica i simbola \\ List of abbreviations and symbols}

KPK - kemijska potrošnja kisika, $\mathrm{mgl}^{-1}$

COD - chemical oxygen demand, $\mathrm{mgl}^{-1}$

$\mathrm{BPK}_{5}$ - biokemijska potrošnja kisika nakon 5 dana, $\mathrm{mgl}^{-1}$

$\mathrm{BOD}_{5}$ - biochemical oxygen demand after 5 days, $\mathrm{mgl}^{-1}$

\section{Literatura}

\section{References}

1. Kakvoća vode - Određivanje indeksa kemijske potrošnje kisika (KPK) - Metoda s malim zatvorenim epruvetama (ISO 15705:2002).

2. Kakvoća vode - Određivanje biokemijske potrošnje kisika nakon n dana (BPKn) - 2. dio: Metoda za nerazrijeđene uzorke (ISO 5815:1989, preinačena; EN 1899-2:1998).

3. Kakvoća vode - Određivanje suspendiranih tvari - Metoda filtriranjem kroz filtar od staklenih vlakana (EN 872:2005).

4. Pravilnik o graničnim vrijednostima emisija otpadnih voda, Narodne novine 80/2013.

5. S. Tedeschi, Zaštita voda, Hrvatsko društvo građevinskih inženjera, Zagreb, 1997., str. 33-94.

6. H. Shi, Point sources of pollution: Local effects and its control, Industrial wastewater-types, amounts and effects. Encyclopaedia of Life Support System, Vol. 1, Eolss Publishers Co. UK, 2009., str. 191-204.

7. H. Amarasinghe Anusha Udeni, H. D. Gunawardena, Y. N. Andjayatunga Amaramali, Correlation between biochemical oxygen demand (BOD) and chemical oxygen demand (COD) for different industrial wastewaters, J. Natn. Sci. Coun. Sri Lanka 21 (1993) 59-266.

8. Pročišćavanje otpadnih voda u prehrambenoj industriji, URL: http:// http://www.ips-konzalting.hr/index.php/hr/usluge-menu-hr/prociscavanje-voda-menu-hr?id=145: prociscavanje-otpadnih-voda-u-prehrambenoj-industriji\&catid=14 (20. 6. 2015.).

9. Pravilnik o graničnim vrijednostima emisija otpadnih voda, Narodne novine 87/2010.

10. Pravilnik o graničnim vrijednostima emisija otpadnih voda, Narodne novine 43/2014.

11. B. Tušar, Ispuštanje i pročišćavanje otpadne vode, Croatia knjiga, Zagreb, 2004., str. 38-53.

12. B. Tušar, Pročišćavanje otpadnih voda, Kigen d. o. o., Zagreb, 2009., str. 19-123.

13. Međimurske vode, Laboratorijsko izvješće o radu biološkog uređaja za mjesec lipanj 2013. godine, Čakovec, 2013.

14. Međimurske vode, Laboratorijsko izvješće o radu biološkog uređaja za mjesec srpanj 2013. godine, Čakovec, 2013.

15. Međimurske vode, Laboratorijsko izvješće o radu biološkog uređaja za mjesec kolovoz 2013. godine, Čakovec, 2013.

\section{SUMMARY \\ Study of Physicochemical Indicators of Water Quality

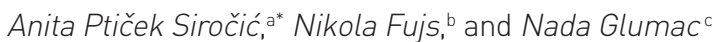

This paper analyses the physicochemical indicators of wastewater quality (chemical oxygen demand (COD), biochemical oxygen demand $\left(\mathrm{BOD}_{5}\right)$, concentrations of suspended solids) during the summer months (June, July and August) in 2013 and 2014 in the wastewater treatment plant Čakovec, which is designed for secondary wastewater treatment. The summer months of 2014 do not show significant deviations in the values of certain indicators, but compared with the same months in 2013, the average monthly values are much lower and within the permitted maximum. Results in June, July, and August 2013 and 2014 indicated efficient wastewater treatment.

\section{Keywords}

Physicochemical indicators, wastewater, wastewater treatment facility, chemical oxygen demand, biochemical oxygen demand, suspended solids

a Faculty of Geotechnical Engineering, University of Zagreb, Hallerova aleja 7, 42000 Varaždin, Croatia

b Tehnix d. o. o., Braće Radića bb, 40320 Donji Kraljevec, Croatia

'Međimurske vode d. o. o., Matice hrvatske 10, 40000 Čakovec, Croatia
Professional paper

Received October 20, 2015 Accepted November 24, 2015 